Supplement of Biogeosciences, 15, 919-936, 2018

https://doi.org/10.5194/bg-15-919-2018-supplement

(C) Author(s) 2018. This work is distributed under

the Creative Commons Attribution 3.0 License.

(c) (1)

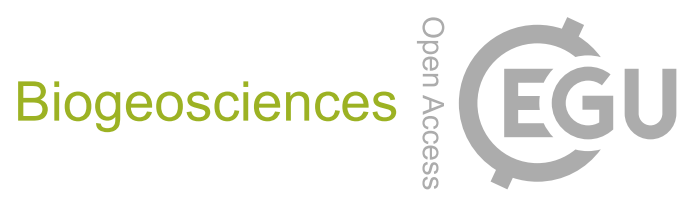

Supplement of

\title{
Influence of climate variability, fire and phosphorus limitation on vegetation structure and dynamics of the Amazon-Cerrado border
}

Emily Ane Dionizio et al.

Correspondence to: Emily Ane Dionizio (emilyy.ane@gmail.com)

The copyright of individual parts of the supplement might differ from the CC BY 3.0 License. 
This document provides supplementary information for the publication "Influence of climate variability, fire and phosphorus limitation on vegetation structure and dynamics of the Amazon-Cerrado border" to appear in Biogeosciences.

\section{S1. Regional phosphorus database}

We used 54 samples of phosphorus content in the soil, of which 52 were obtained via the Mehlich-1 extraction $\left(\mathrm{H}_{2} \mathrm{SO}_{4}, 0.025 \mathrm{~mol} \mathrm{~L}^{-1}+\mathrm{HCl} 0.05 \mathrm{~mol} \mathrm{~L}^{-1}\right)$ 1:10 soil: solution ratio, and two are direct measurements of total phosphorus content $\left(\mathrm{P}_{\text {total }}\right)$ in the soil. In addition to these samples collected in the field, a phosphorus soil map of the Amazon was also used (Quesada et al., 2010).

All 54 samples of P content were provided by researchers from the UNEMAT State University of Mato Grosso, collected for different vegetation types ranging from sparse physiognomies like Campo de Murundus, open flooded field, Cerrado típico to more dense forest formations such as Cerradão, semideciduous forest, evergreen seasonal forest and gallery forest in the Amazon-Cerrado transition region in the state of Mato Grosso.

The database of Quesada et al. (2010) provides data of physicochemical properties of the soil, and Hedley fractionation data with eight different fractions of phosphorus content in the soil, including: phosphorus extracted by resin $\left(\mathrm{P}_{\text {resin }}\right), \mathrm{P}_{\text {total }}$ and residual. The location, name of the experimental sites, value of $\mathrm{P}_{\text {total }}, \mathrm{P}_{\text {Resin }}$ and clay percent used to establish the relationship between $\mathrm{P}_{- \text {-Mehlich-1 }}$ and $\mathrm{P}_{\text {total }}$ are shown in Table S1.

Based on the Freire (2001) equation, the amount of phosphorus remaining in the soil, i.e., the existing amount of $\mathrm{P}$ in the soil $\left(\mathrm{P}_{\text {rem }}\right)$ was estimated for each site, based on their clay content: 


$$
\mathrm{P}_{\text {rem }}=52.44-0.9646 \mathrm{C}+0.005 \mathrm{C}^{2} \quad \mathrm{R}^{2}=0.747
$$

where $\mathrm{P}_{\text {rem }}$ is expressed in $\mathrm{mg} \mathrm{L}^{-1}$ and $\mathrm{C}$ is the clay content in $\% . \mathrm{P}_{\text {rem }}$ is the $\mathrm{P}$ concentration that remains in solution after shaking soil with $0.01 \mathrm{~mol} \mathrm{~L}^{-1} \mathrm{CaCl}_{2}$ containing $60 \mathrm{mg} \mathrm{L}^{-1} \mathrm{P}$ (Alves and Lavorenti, 2006).

After obtaining of the remaining values $\left(\mathrm{P}_{\text {rem }}\right)$, it was necessary to estimate the phosphorus maximum adsorption capacity (CMAP) of each soil, in order to calculate how much phosphorus each soil is capable of adsorbing.

Based on significative data from several studies (Bognola, 1995; Campello et al., 1994; Fabres, 1986; Gonçalves, 1988; Ker, 1995; Moreira, 1988; Muniz, 1983; Novelino, 1999; Paula, 1993), Neves (2000) proposed Equation (2) to calculate CMAP from $\mathrm{P}_{\text {rem }}$ :

$$
\mathrm{CMAP}=1816.1-373.72 \log \mathrm{P}_{\text {rem }} \quad \mathrm{R}^{2}=0.751
$$

where CMAP is expressed in $\mathrm{mg} \mathrm{kg}^{-1}$ and $\mathrm{P}_{\text {rem }}$ in $\mathrm{mg} \mathrm{L}^{-1}$.

Knowing the CMAP, Neves (2000) also proposed a robust model (Equation 3), which estimates how much the Mehlich-1 extraction is able to removing the $\mathrm{P}$ added in each soil sample $\left(\mathrm{P}_{\text {-Mehlich-1 }} / \mathrm{P}_{\text {Adc }}\right)$. This relationship was adjusted based on 31 soil samples data from the work of Bahia-Filho (1982), Muniz (1983), Gonçalves (1988) and Novelino (1999);

$\frac{\mathrm{P}_{- \text {Mehlich-1 }}}{\mathrm{P}_{\text {Adc }}}=380.96 \mathrm{CMAP}^{-1.2101} \quad \mathrm{R}^{2}=0.734,(\mathrm{p}<0.001)$

where $\mathrm{P}_{\text {Adc }}$ is the added dose of $\mathrm{P}$ in soil expressed in $\mathrm{mg} \mathrm{kg}^{-1}$.

7 Finally, knowing $\mathrm{P}_{- \text {Mehlich-1 }} / \mathrm{P}_{\text {Adc }}, \mathrm{P}_{\text {resin }} / \mathrm{P}_{- \text {Mehlich-1 }}$ was estimated using the Equation (4) established by Neves (2000) with $r=0.899, n=26$.

$$
\frac{\mathrm{P}_{\text {resin }}}{\mathrm{P}_{- \text {Mehlich-1 }}}=0.5553\left(\frac{\mathrm{P}_{- \text {Mehlich-1 }}}{\mathrm{P}_{\text {Adc }}}\right) 0.6002 \quad \mathrm{R}^{2}=0.808,(\mathrm{p}<0.001)
$$


where $\mathrm{P}_{\text {resin }}$ is expressed in $\mathrm{mg} \mathrm{kg}^{-1}$.

With the $\mathrm{P}_{\text {resin }}$ values and the ratio estimated by Equation (4), $\mathrm{P}_{\text {-Mehlich-1 }}$ values for all stations in Quesada et al. (2010) were estimated ( $\mathrm{P}_{-} \mathrm{m} 1$ _est, expressed in $\left.\mathrm{mg} \mathrm{kg}^{-1}\right)$. Table 2 shows the estimates obtained by Equations (1), (2), (3) and (4) for the 26 sites in the Amazon.

Obtaining $\mathrm{P}_{\_}$m_est values for locations where data for clay content and $\mathrm{P}_{\text {total }}$ $\left(\mathrm{mg} \mathrm{kg}^{-1}\right)$ were available enabled the development of a linear regression model (Equation 5) that estimates $\mathrm{P}_{\text {total }}$ from $\mathrm{P}_{-} \mathrm{m} 1_{-}$est $\left(\mathrm{mg} \mathrm{kg}^{-1}\right)$ and $\mathrm{C}(\%)$ with $\mathrm{r}=0.639$.

$$
P_{\text {total }}=72.4628+0.639\left(P_{\text {_m1_est }} C\right) \quad R^{2}=0.408,(p<0.001)
$$

60 Although the $\mathrm{R}^{2}$ value is low, the regression is significant at $\mathrm{p}<0.01$. The product 1 ( $\mathrm{P}_{-} \mathrm{m1} \_$est $\mathrm{C}$ ) was used to correct the effect of soil clay contribution on $\mathrm{P}_{\text {-Mehlich-1 values, }}$ 2 which tends to remove smaller amounts of $\mathrm{P}$, for high values of clay. Applying the 3 Equation (5) to the observated data, $\mathrm{P}_{\text {total }}$ was estimated for 54 field samples collected in 4 Mato Grosso. These results are presented in Table S2 and were incorporated to the 65 regional dataset of Quesada et al. (2010). Depending on the spatial distribution of the 6 samples, the average for the $\mathrm{P}_{\text {total }}$ values was calculated inside each $1^{\circ} \times 1^{\circ}$ pixel. 
Table S1. Phosphorus samples in $\mathrm{P}_{\text {resin }}$ and clay fraction of different plots in the Brazilian Amazon from the database Quesada et al. (2010). Estimates used to obtain

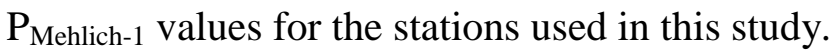

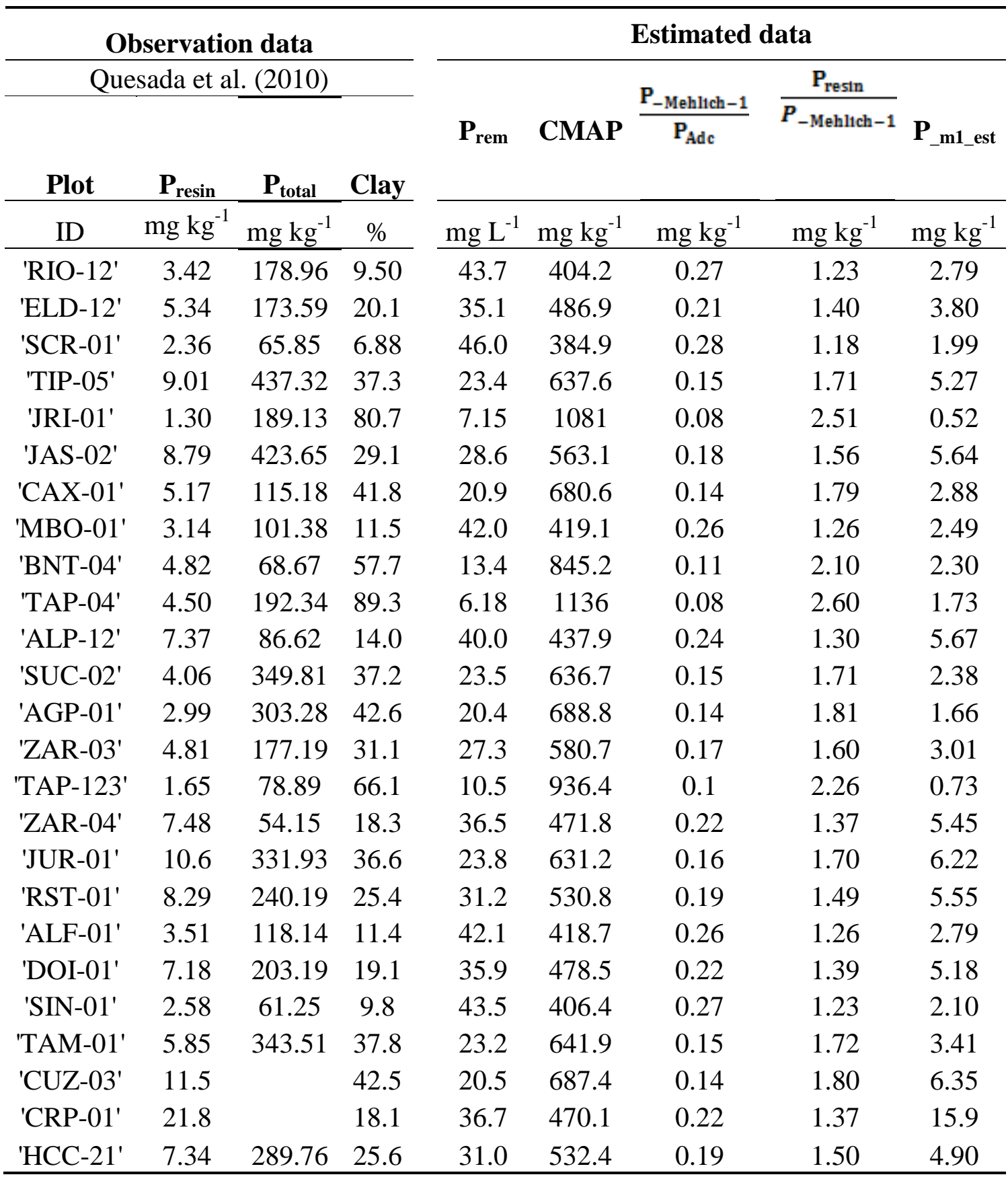


Table S2. Phosphorus content data $\left(\mathrm{P}_{\text {-Mehlich-1 }}\right)$ and clay percentage for the 54 soil

samples collected in the Amazon-Cerrado transition region and $\mathrm{P}_{\text {total }}$ estimates.

\begin{tabular}{|c|c|c|c|c|c|c|c|}
\hline \multicolumn{4}{|c|}{ Location } & \multirow[t]{2}{*}{ Physiognomy } & \multirow{2}{*}{$\begin{array}{c}\text { Clay } \\
\% \\
\end{array}$} & \multirow{2}{*}{$\begin{array}{l}\text { P-Mehlich-1 } \\
\text { mg dm }^{-3} \\
\end{array}$} & \multirow{2}{*}{$\frac{P_{\text {total }}}{\mathrm{mg} \mathrm{dm}^{-3}}$} \\
\hline Latitude & Longitude & $\mathbf{n}$ & pixel & & & & \\
\hline-15.55 & -50.10 & 1 & 1 & Cerrado rupestre ${ }^{a}$ & 30.6 & 0.89 & 89.87 \\
\hline-15.54 & -50.10 & 2 & 1 & Cerrado típico $^{b}$ & 34.7 & 0.2 & 76.9 \\
\hline-14.17 & -51.76 & 3 & 2 & Cerrado ralo ${ }^{c}$ & 21.06 & 2.28 & 103.14 \\
\hline-14.17 & -51.77 & 4 & 2 & Cerrado ralo ${ }^{c}$ & 29.97 & 1.3 & 97.36 \\
\hline-14.15 & -51.76 & 5 & 2 & Cerrado típico ${ }^{b}$ & 40.53 & 2.93 & 148.35 \\
\hline-14.16 & -51.77 & 6 & 2 & Cerrado típico $^{b}$ & 35.41 & 1.11 & 97.58 \\
\hline-14.71 & -52.35 & 7 & 3 & Cerrado típico $^{b}$ & 35.84 & 3 & 141.17 \\
\hline-14.71 & -52.35 & 8 & 3 & Cerrado típico $^{b}$ & 48.16 & 0.84 & 98.31 \\
\hline-14.71 & -52.35 & 9 & 3 & Cerrado típico $^{b}$ & 49.33 & 0.42 & 85.7 \\
\hline-14.82 & -52.17 & 10 & 3 & Semi deciduous Forest & 21.5 & 3.18 & 116.15 \\
\hline-14.71 & -52.35 & 11 & 3 & Cerrado típico ${ }^{b}$ & 17.28 & 0.34 & 76.22 \\
\hline-14.71 & -52.35 & 12 & 3 & Cerrado típico ${ }^{b}$ & 17.71 & 0.13 & 73.93 \\
\hline-14.70 & -52.35 & 13 & 3 & Cerradão ${ }^{d}$ & 21.04 & 0.26 & 75.96 \\
\hline-14.70 & -52.35 & 14 & 3 & Cerradão $^{d}$ & 24.35 & 0.1 & 73.96 \\
\hline-14.69 & -52.35 & 15 & 3 & Cerradão $^{d}$ & 21.03 & 5.46 & 145.83 \\
\hline-14.69 & -52.35 & 16 & 3 & Cerradão $^{d}$ & 33.53 & 3.8 & 153.88 \\
\hline-14.69 & -52.35 & 17 & 3 & Cerradão $^{d}$ & 40.47 & 1.9 & 121.6 \\
\hline-14.69 & -52.35 & 18 & 3 & Cerradãoo $^{d}$ & 44.03 & 0.8 & 94.97 \\
\hline-14.69 & -52.35 & 19 & 3 & Cerradão $^{d}$ & 45.24 & 0.3 & 81.13 \\
\hline-14.72 & -52.36 & 20 & 3 & Gallery Forest & 15.02 & 0.87 & 80.81 \\
\hline-14.72 & -52.36 & 21 & 3 & Gallery Forest & 10.45 & 6.94 & 118.8 \\
\hline-14.72 & -52.36 & 22 & 3 & Gallery Forest ${ }^{\mathrm{f}}$ & 11.65 & 1.71 & 85.19 \\
\hline-13.10 & -53.39 & 23 & 4 & Riparian Forest ${ }^{\mathrm{f}}$ & 43 & 26 & 786.86 \\
\hline-13.10 & -53.39 & 24 & 4 & Riparian Forest ${ }^{\mathrm{f}}$ & 49 & 18 & 636.06 \\
\hline-13.00 & -50.25 & 25 & 5 & Cerrado rupestre $^{a}$ & 4.44 & 2.44 & 79.39 \\
\hline-12.38 & -50.93 & 26 & 6 & Campo de Murundus ${ }^{g}$ & 39.33 & 2.3 & 130.27 \\
\hline-12.36 & -50.93 & 27 & 6 & Campo de Murundus ${ }^{g}$ & 29.52 & 3.3 & 134.71 \\
\hline-12.56 & -50.92 & 28 & 6 & Campo de Murundus ${ }^{g}$ & 22 & 3.3 & 118.85 \\
\hline-12.04 & -50.73 & 29 & 6 & Campo de Murundus ${ }^{g}$ & 38.48 & 0.7 & 89.67 \\
\hline-12.57 & -50.91 & 30 & 6 & Campo de Murundus ${ }^{g}$ & 39.11 & 1.7 & 114.95 \\
\hline-12.62 & -50.82 & 31 & 6 & Campo de Murundus ${ }^{g}$ & 25.56 & 2.4 & 111.66 \\
\hline-12.43 & -50.72 & 32 & 6 & Campo de Murundus ${ }^{g}$ & 29.11 & 2.3 & 115.25 \\
\hline-12.23 & -50.77 & 33 & 6 & Campo de Murundus ${ }^{g}$ & 30.77 & 2.3 & 117.69 \\
\hline-12.38 & -50.94 & 34 & 6 & Campo de Murundus ${ }^{g}$ & 37.46 & 5.2 & 196.93 \\
\hline-12.38 & -50.94 & 35 & 6 & Campo de Murundus ${ }^{g}$ & 39.34 & 4 & 173.02 \\
\hline-12.38 & -50.93 & 36 & 6 & open field $^{\mathrm{f}}$ & 32.45 & 1.6 & 105.64 \\
\hline
\end{tabular}




\begin{tabular}{|c|c|c|c|c|c|c|c|}
\hline \multicolumn{4}{|c|}{ Location } & \multirow[t]{2}{*}{ Physiognomy } & \multirow{2}{*}{$\frac{\text { Clay }}{\%}$} & \multirow{2}{*}{$\begin{array}{c}\text { P.Mehlich-1 }_{\text {- }} \\
\text { mg dm}^{-3}\end{array}$} & \multirow{2}{*}{$\frac{P_{\text {total }}}{\mathrm{mg} \mathrm{dm}^{-3}}$} \\
\hline Latitude & Longitude & $\mathbf{n}$ & pixel & & & & \\
\hline-12.38 & -50.93 & 37 & 6 & open field $^{f}$ & 20.78 & 2 & 99.02 \\
\hline-12.36 & -50.93 & 38 & 6 & open field ${ }^{f}$ & 17.08 & 1.6 & 89.93 \\
\hline-12.04 & -50.73 & 39 & 6 & open field ${ }^{\mathrm{f}}$ & 22.83 & 0.8 & 84.13 \\
\hline-12.57 & -50.91 & 40 & 6 & open field ${ }^{\mathrm{f}}$ & 24.95 & 0.7 & 83.62 \\
\hline-12.62 & -50.82 & 41 & 6 & open field ${ }^{\mathrm{f}}$ & 20.77 & 2.2 & 101.66 \\
\hline-12.43 & -50.72 & 42 & 6 & open field ${ }^{\mathrm{f}}$ & 19.55 & 1.6 & 92.45 \\
\hline-12.23 & -50.77 & 43 & 6 & open field ${ }^{f}$ & 27.03 & 1.9 & 105.28 \\
\hline-12.38 & -50.94 & 44 & 6 & open field ${ }^{f}$ & 29.93 & 3.1 & 131.75 \\
\hline-12.38 & -50.94 & 45 & 6 & open field $^{\mathrm{f}}$ & 30.75 & 0.9 & 90.15 \\
\hline-12.83 & -52.35 & 46 & 7 & Seasonal Evergreen Forest & 49 & - & 141.54 \\
\hline-12.81 & -51.85 & 47 & 8 & Seasonal Evergreen Forest & 16 & - & 117.03 \\
\hline-11.18 & -50.23 & 48 & 9 & Cerrado denso $^{h}$ & 3.96 & 2.71 & 79.32 \\
\hline-11.18 & -50.23 & 49 & 9 & Cerradão ${ }^{d}$ & 4.16 & 1.66 & 76.88 \\
\hline-11.17 & -50.23 & 50 & 9 & Cerrado típico $^{b}$ & 3.56 & 1.45 & 75.76 \\
\hline-11.86 & -50.72 & 51 & 10 & open field ${ }^{\mathrm{f}}$ & 41.63 & 2 & 125.67 \\
\hline-11.86 & -50.72 & 52 & 10 & Campo de Murundus ${ }^{g}$ & 47.65 & 2.8 & 157.72 \\
\hline-9.11 & -54.23 & 53 & 11 & Cerrado rupestre ${ }^{a}$ & 4.56 & 4.17 & 84.61 \\
\hline-9.79 & -50.43 & 54 & 12 & Semi deciduous Forest & 18.36 & 2.04 & 96.4 \\
\hline
\end{tabular}

${ }^{a}$ Cerrado rupestre: a tree-shrub vegetation that grows in areas of accentuated topography with many rock outcrops and shallow soils, where individual trees establish themselves in clefts in the rocks so that their densities will vary as a function of the specific conditions of each site (Ribeiro and Walter, 2008).

${ }^{b}$ Cerrado típico: a vegetation of trees and shrubs fairly regular and usually not more tall (approximately $4 \mathrm{~m})$ (Ribeiro and Walter, 2008).

${ }^{c}$ Cerrado ralo: a vegetation that is more open than Cerrado típico; the trees not exceeding 2 to 3 meters in height, covering from 5 to $20 \%$ of the soil (Ribeiro and Walter, 2008).

${ }^{d}$ Cerradão: a dense and tall woodland formation (Ribeiro and Walter, 2008).

${ }^{g}$ Campo de Murundus: a typical landscape of Central Brazil characterized by countless rounded earth mounds (the 'murundus'), which are covered by woody 'Cerrado' vegetation and are found scattered over a grass-covered surface (the 'campo') (Ribeiro and Walter, 2008).

${ }^{h}$ Cerrado denso: this vegetation is more dense than Cerrado típico; the trees exceeding 2 to 3 meters in height, and covered with a woody cover ranging from 10 to $60 \%$ (Ribeiro and Walter, 2008).

\section{S2. Difference between the global $\mathbf{P}_{\text {total }}$ map and regional $\mathbf{P}_{\text {total }}$ map (PG-PR)}

The spatial difference of the soil phosphorus content between the global $\mathrm{P}_{\text {total }}$ map (PG) and the regional map (PR) showed that global data underestimates the $\mathrm{P}_{\text {total }}$ values in some Amazon-Cerrado transition areas, mainly in western Amazonia. PG overestimations are observed in northern Amazonia and in most of the Cerrado biome area. The differences between the absolute values of total phosphorus at a spatial 
97 resolution of $1^{\circ} \times 1^{\circ}$ varied in the range of $\pm 180 \mathrm{mg} \mathrm{kg}^{-1}$, with an average of $98 \quad 24.19 \mathrm{mg} \mathrm{kg}^{-1}$ (Figure $\mathrm{S} 1$ ).

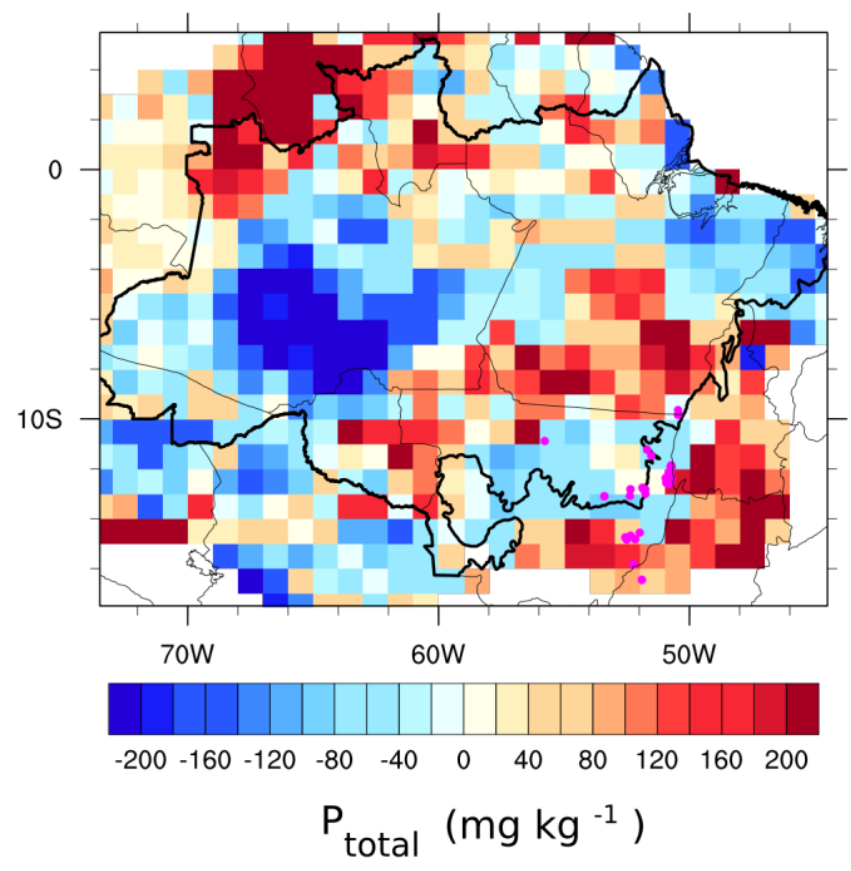

Figure S1. Difference between the global $\mathrm{P}_{\text {total }}$ map (Yang et al., 2013) and regional $\mathrm{P}_{\text {total }}$ map (PG-PR) in $\mathrm{mg} \mathrm{kg}^{-1}$. The thick black line delimits the Amazon and Cerrado biomes.

S3. Spatial variability of precipitation and temperature from CRU databases

The seasonality of precipitation for Amazon and Cerrado biomes used in this study is shown in Figure S2. The dry season duration is larger in the Cerrado domain (Figure S2a) than in the Amazonia domain (Figure S2b). In the Cerrado, dry season comprise a period of about 6 months with little or no rain.

Spatial variability of precipitation and temperature are shown in Figures S3 and $\mathrm{S} 4$, respectively. These figures plot the difference between the average of the last 10 years of CV (1999-2008) and average climate CA (1961-1990). highlighting the spatial variability of these climate variable throughout the study area. When comparing the 
114 interannual climate variability with the average climate, it is possible to observe that

115 precipitation decreases (Figure S3) and temperature increases up to $1.5^{\circ} \mathrm{C}$ (Figure S4) in

116 central Cerrado in October, November, December and January. The lower precipitation

117 associated with higher temperatures in central Cerrado can explain a low biomass, low

118 LAI vegetation and savanna existence without fire disturbance. Note that this is a 10-

119 year subset of the CV database. The actual year-to-year variations present much more 120 intense amplitudes.

121
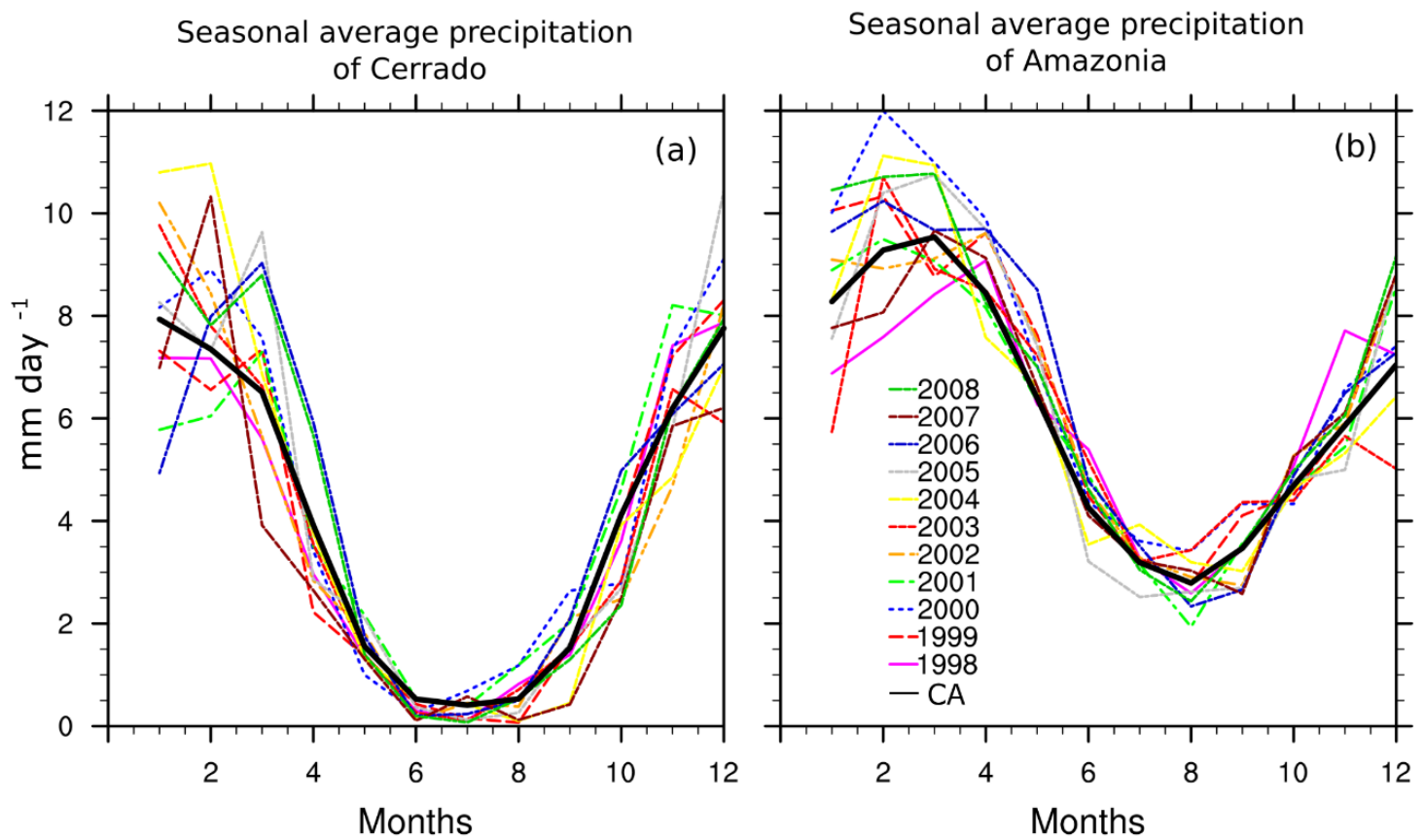

122

Figure S2. Seasonal precipitation of Amazon and Cerrado domains for average climate

124 (CA) - black line - and the last ten years of interannual- climate variability (CV) - color 125 lines. 
Spatial variability of precipitation (CV - CA)
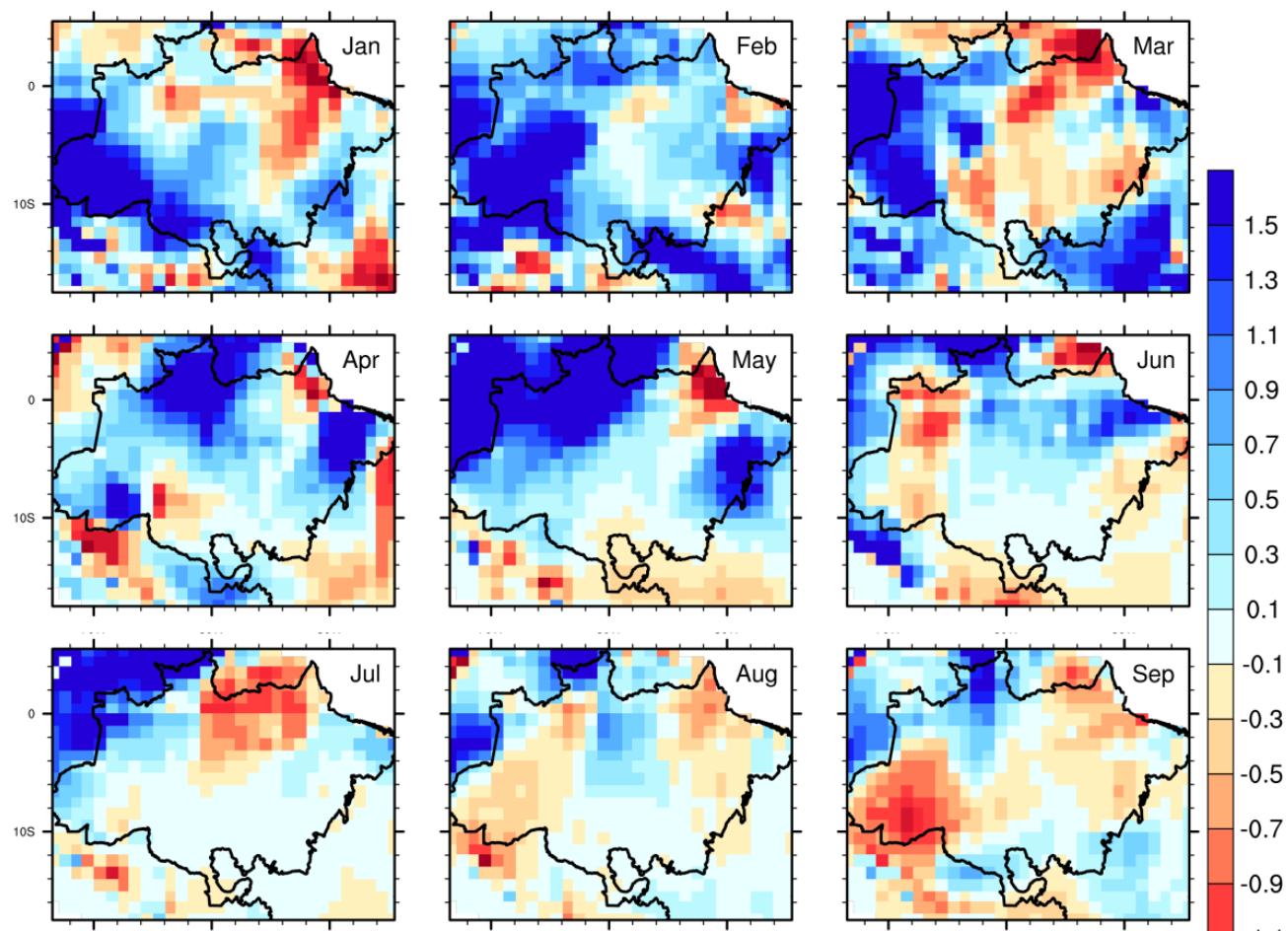

ते
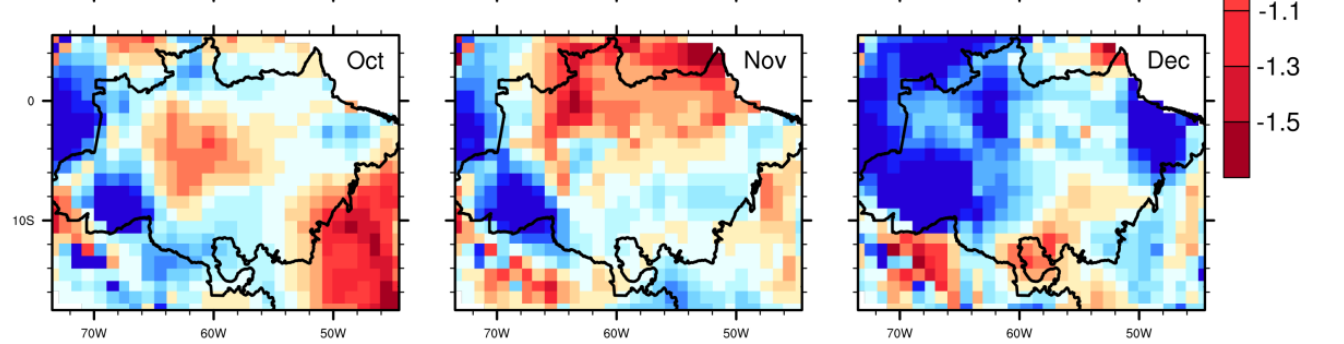

Figure S3. Spatial variability of precipitation for the study area considering the average of the last 10 years of CV (1999-2008) and average climate CA (1961-1990). 
Spatial variability of temperature $(\mathrm{CV}-\mathrm{CA})$
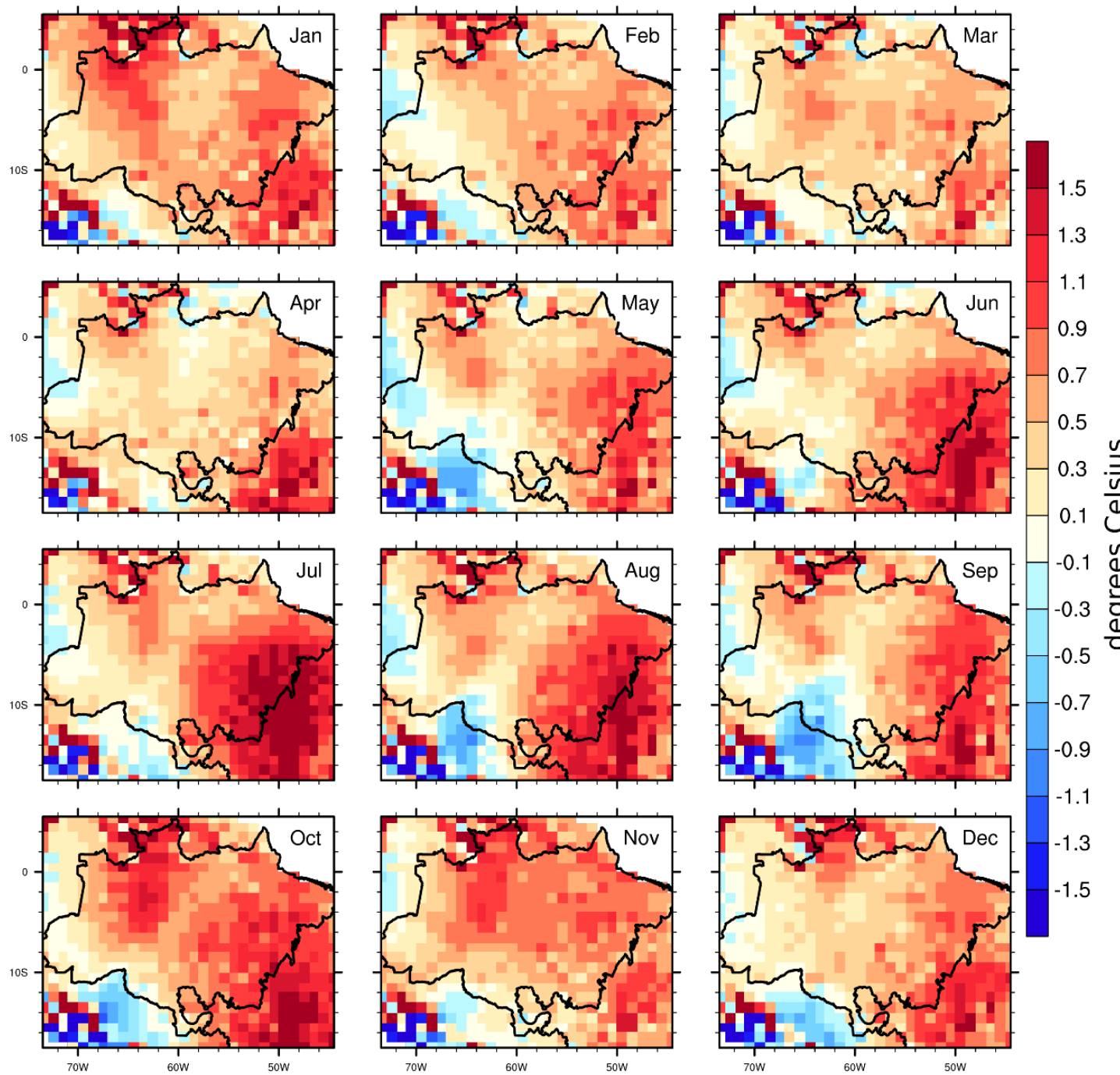

Figure S4. Spatial variability of temperatures for the study area considering the average

of the last 10 years of CV (1999-2008) and average climate CA (1961-1990).

\section{References}

Alves, M. E. and Lavorenti, A.: Remaining Phosphorus Estimate Through

Multiple Regression Analysis, Pedosphere, 16(5), 566-571, doi:10.1016/S10020160(06)60089-1, 2006.

Bahia Filho, A. F. C.: Índices de disponibilidade de fósforo em latossolos do

Planalto Central com diferentes características texturais e mineralógicas, Ph.D thesis,

Federal University of Viçosa, Brazil,178pp., 1982. 
Bognola, I. A.: Caracterização química, física e mineralógica de solos intermediários entre Latossolos Brunos e Latossolos Roxos, M.S thesis, Federal University of Viçosa, Brazil, 205pp., 1995.

N. F.: Avaliação da reversibilidade de fósforo não-lábil para lábil em solos com diferentes características, Rev. Bras. Ciência do Solo, 18, 157-165, 1994.

Fabres, A. S.: Disponibilidade de fósforo em solos e concentrações críticas de diferentes frações de fósforo em plantas de alface cultivadas em amostras de diferentes Brazil,144pp., 2001. 
fertilizados com fósforo, avaliada por diferentes métodos de extração, Ph.D thesis, Federal University of Viçosa, Brazil, 70pp., 1999.

171 latossolos de Minas Gerais, M.S thesis, Federal University of Viçosa, Brazil, 58pp., 1721993.

173 Quesada, C. A., Lloyd, J., Schwarz, M., Patiño, S., Baker, T. R., Czimczik, C., 174 Fyllas, N. M., Martinelli, L., Nardoto, G. B., Schmerler, J., Santos, a. J. B., Hodnett, M. 175 G., Herrera, R., Luizão, F. J., Arneth, A., Lloyd, G., Dezzeo, N., Hilke, I., Kuhlmann, I., 176 Raessler, M., Brand, W. A., Geilmann, H., Filho, J. O. M., Carvalho, F. P., Filho, R. N. 177 A., Chaves, J. E., Cruz, O. F., Pimentel, T. P. and Paiva, R.: Variations in chemical and 178 physical properties of Amazon forest soils in relation to their genesis, Biogeosciences, 179 7, 1515-1541, doi:10.5194/bg-7-1515-2010, 2010.

181 Cerrado, in Cerrado: ecologia e flora, pp. 153-212, 2008. phosphorus for global biogeochemical modeling, Biogeosciences, 10, 2525-2537, doi:10.5194/bg-10-2525-2013, 2013. 